\title{
Energy-Efficient Features to Upgrade Attic Slabs of Historical Buildings (Case Study of Saint-Petersburg)
}

\author{
Vera Murgul ${ }^{1, *}$ \\ ${ }^{1}$ St. Petersburg State Polytechnical University, Politekhnicheskaya, 29, Saint-Petersburg, 195251, \\ Russia
}

\begin{abstract}
Thermal insulation of attic slabs is a conventional measure during the energy-efficiency improvement of residential buildings. A specific problem is warmth-insulation of attic slabs in historical buildings, which are the objects of cultural heritage, and for them the main modernization rule is the preservation of historical interiors (ceiling is a protection subject). The article exposes design of reconstruction of attic slabs while preserving the existing historical ceiling and warmth-insulation design is proposed.
\end{abstract}

\section{Introduction}

Traditionally, energy efficiency improvement of old buildings includes warming of attic slabs (in case when the mansard is absent). The historical building in St. Petersburg of preindustrial development period was chosen as the object of this study.

The peculiarity of the historical buildings in St. Petersburg is the existence of protected interiors, particularly ceilings with rich stucco decoration. Reconstruction of the attic slab in such buildings is hampered by the need of preserving historical ceiling. At the same time load bearing capacity of wooden beams in historical attic slabs is already exhausted.

Studying the Energy Performance of Historic Buildings is presented in the number of studies [1-5]. Review of structures and materials of attic floors in apartment houses of St. Petersburg, which were used for the construction in different periods, is given in $[6,7]$. As a general rule, for now, a significant part of historical buildings of pre-industrial period have already been reconstructed with partial or complete replacement of the slabs due to material wear.

Numerous technical surveys of pre-industrial period buildings, which were performed by the author, revealed the diversity and uniqueness of the designs made in $18-19^{\text {th }}$ centuries in St. Petersburg. Nevertheless, it is possible to allocate the established basic designs of floors in historical buildings of St. Petersburg in $18-19^{\text {th }}$ centuries.

This article will expose the main types of attic slabs in historical buildings before and after renovation due to material wear.

The project of reconstruction including warmth insulating of attic slabs in historical building while preserving the invaluable ceiling was proposed.

\footnotetext{
*Corresponding author: october6@list.ru
} 


\section{Features of attic slabs in historical pre-industrial period buildings of Saint-Petersburg}

A survey of structures in old residential housing was conducted in Saint-Petersburg during 1968-1972 by the means of special Lenzhilproekt institute methodology [8].

The historical St. Petersburg residential buildings constructed before 1915 can be divided on five types of floors (Table 1) [8].

Table 1. Types of slabs in historical residential buildings

\begin{tabular}{lcc}
\hline \multicolumn{1}{c}{ Floor type } & $\begin{array}{c}\text { Area, } \\
{\left[\text { million }{ }^{2}\right]}\end{array}$ & $\begin{array}{c}\text { The average standard } \\
\text { terms of service, [years] }\end{array}$ \\
\hline 1. Plastered wood & 13 & 60 \\
\hline 2. Plastered wood on steel beams & 3.5 & 80 \\
\hline $\begin{array}{l}\text { 3. With brick and concrete filling on steel } \\
\text { beams }\end{array}$ & 0.5 & 125 \\
\hline 4. Circular brick vaults & 0.5 & - \\
\hline $\begin{array}{l}\text { 5. Precast, made of reinforced concrete, set } \\
\text { after complex overhaul }\end{array}$ & 4.5 & 125 \\
\hline
\end{tabular}

Note: Survey data for 1931. Concrete floors are made during complex overhaul.

\subsection{Wooden slabs}

Wooden slabs can have diverse cross-section of beam: beams with a selected slot (Fig. 1a), with the selected "skull" (Fig. 1b), hewn on two edge for the attic slabs (Fig. 1, c). [7]
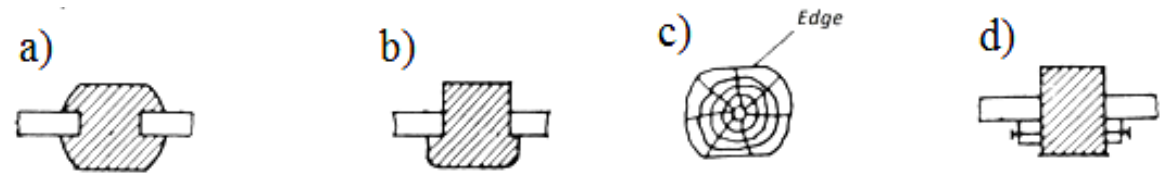

Fig. 1. The cross sections of wooden slabs beams. a) beam with a selected slot; b) a beam with hewn "skulls"; c) beam with two cut corners; d) from a of timber bar nailed with cranial bars

"Grease" is used for heat and steam insulation of ceilings. The lubricant must be lightweight in order to not burden the beam, refractory to serve as at least some obstacle to the rapid spread of fire from the upper floors to the bottom, and finally, should not contribute to the decay or deterioration of beams and subfloors [9]. Lubricant is based on clay and brick. To maintain the lubricant there is subfloor. Wooden subfloors can be divided to sectional and laid ones (Fig. 2). They have different beam joining.

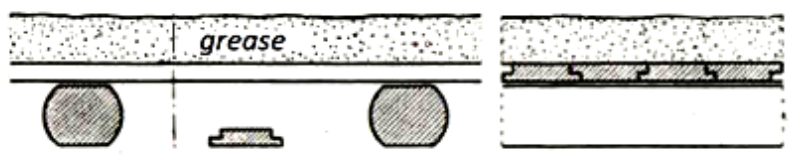

Fig. 2. Attic slab design with laid subfloor

Laid subfloors are arranged of 6-inch wooden boards, set entirely on the beams and combined in the quarter. To install sectional subfloors (or conjunctions) skulls are cut in the beams or wooden bars are nailed to them. 

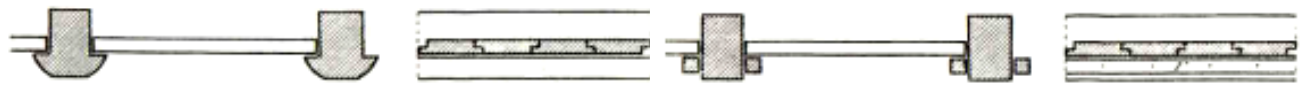

Fig. 3. Floor design with sectional subfloor.

Debris were put in a layer of $8-10 \mathrm{~cm}$ directly over the subfloor conjunction. When wooden bars began to be used as beams, the connection of boards in conjunctions was made back to back and covered with one layer of roofing felt before filling with bebris.

Rarely met hardwood slabs of separate structure where the load from the the ceiling structure and the floor is perceived by the individual supporting beam systems. The height of these slabs is more than 0.5 meters (Fig. 4).

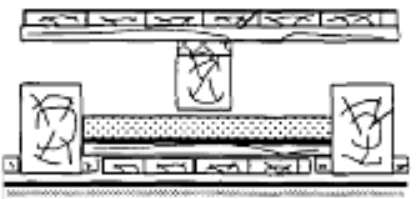

Fig. 4. Wooden slabs of separate structure

Brick grease was used for thermal insulation of the attic space. The kneaded clay layer of 2-4 cm was pressed by a half-brick, so that individual bricks abut each other. The clay squeezed during that filled joints.

After drying seams for filling the voids were spilled with lime liquid mortar. Area of wooden floors in the old residential houses in St. Petersburg at the beginning of the $80 \mathrm{~s}$. of XX century was about 13 million $\mathrm{m}^{2}$, about $2 \%$ of this area have valuable architectural decoration.

\subsection{Floors on steel beams}

Table 2 lists the specifications which are affecting the heat-insulation parameters of building envelope and which are required for builders during installation of steel beams. There were also numerous recommendations, which in practice were often neglected. For example, recommendations said to plaster the ceiling over the hem. But in houses with cheap apartments boards in conjunctions were cut, then sutured with shingles and plastered ceilings without the hem. It all depended on what goals the owner of the house pursued and of a durability presumed during construction. Many old houses can not be repaired because of the condition of main structures.

Table 2. Technical Requirements for overlaps on the metal beams

$$
\text { Requirements }
$$

Causes

\begin{tabular}{ll}
$\begin{array}{l}\text { Minimum sealing of the ends of beams } \\
\text { with spans up to } 4 \mathrm{~m}-15 \mathrm{~cm} ; 6 \mathrm{~m}-18 \\
\mathrm{~cm} \text {, up to } 9 \mathrm{~m}-20 \mathrm{~cm}\end{array}$ & $\begin{array}{l}\text { These dimensions provide a reliable connection } \\
\text { to the support beam }\end{array}$ \\
\hline $\begin{array}{l}\text { The minimum distance from the beam } \\
\text { end to the front surface of the outer wall } \\
\text { should be not less than } 40 \mathrm{~cm}\end{array}$ & $\begin{array}{l}\text { Such distance prevents end of the beam from } \\
\text { freezing }\end{array}$ \\
\hline $\begin{array}{l}\text { When making attic overlaps setting of } \\
\text { laid floors is required }\end{array}$ & $\begin{array}{l}\text { Setting laid floors in attics with steel beams is } \\
\text { more important than with wooden ones, } \\
\text { because board row and a grease layer prevent } \\
\text { steel from freezing }\end{array}$ \\
\hline
\end{tabular}


Thus, considering historical buildings of pre-industrial period as an object of study, 3 main types of attic floors can be considered: wooden floors on the wooden beams, wooden floors on steel beams, stone vaulted ceiling on steel beams .

\section{The results of field surveys of historical buildings}

The building at the following address was surveyed: St. Petersburg, Nevsky avenue, 41 (palace of Beloselsky-Belozersky) [10]. Figures 5, 6.

Year of construction - 1800; year of reconstruction - 1848 .

Attic floor of mixed type.

- On the metal beams of the I-sections № $18,22(\mathrm{~b}=18.98 \mathrm{~mm})$, packed in increments of $90-100 \mathrm{~cm}$. Insulation is a clay-brick grease on the wooden filling and construction debris on the concrete filling. Wooden boards filling and concrete vaulted filling between the beams;

- On the wooden beams made of hewn logs with a diameter of 20-40 cm and beams with cross-section $7 \times 15 \mathrm{~cm}$, packed in increments of 70-150 cm: insulation - clay-brick grease on laid floor. Part of the beams are one end embedded in the masonry of interior walls, the other end is rested on the beams of hewn logs with a diameter of $32 \mathrm{~cm}$, arranged along the exterior walls.

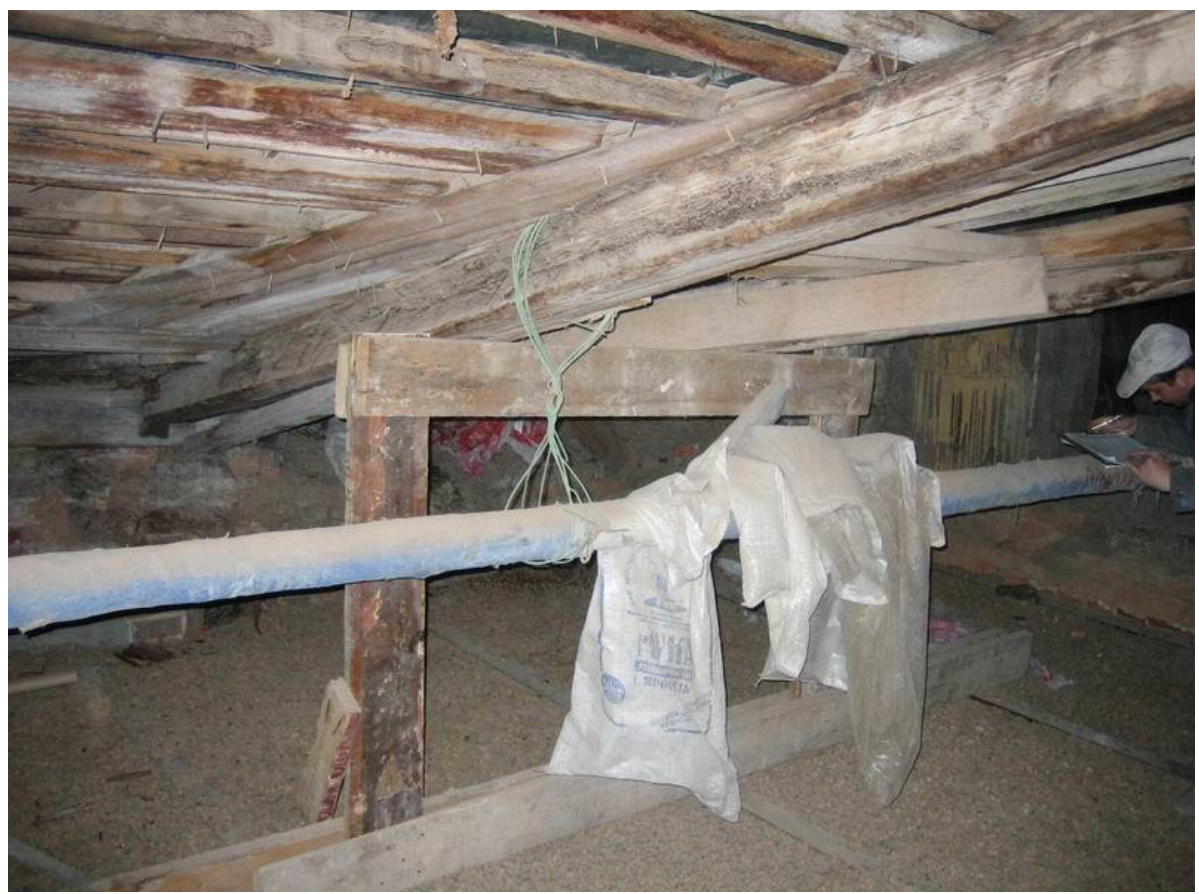

Fig. 5. Attic overlap on steel beams. 


\section{TPACEE-2016}

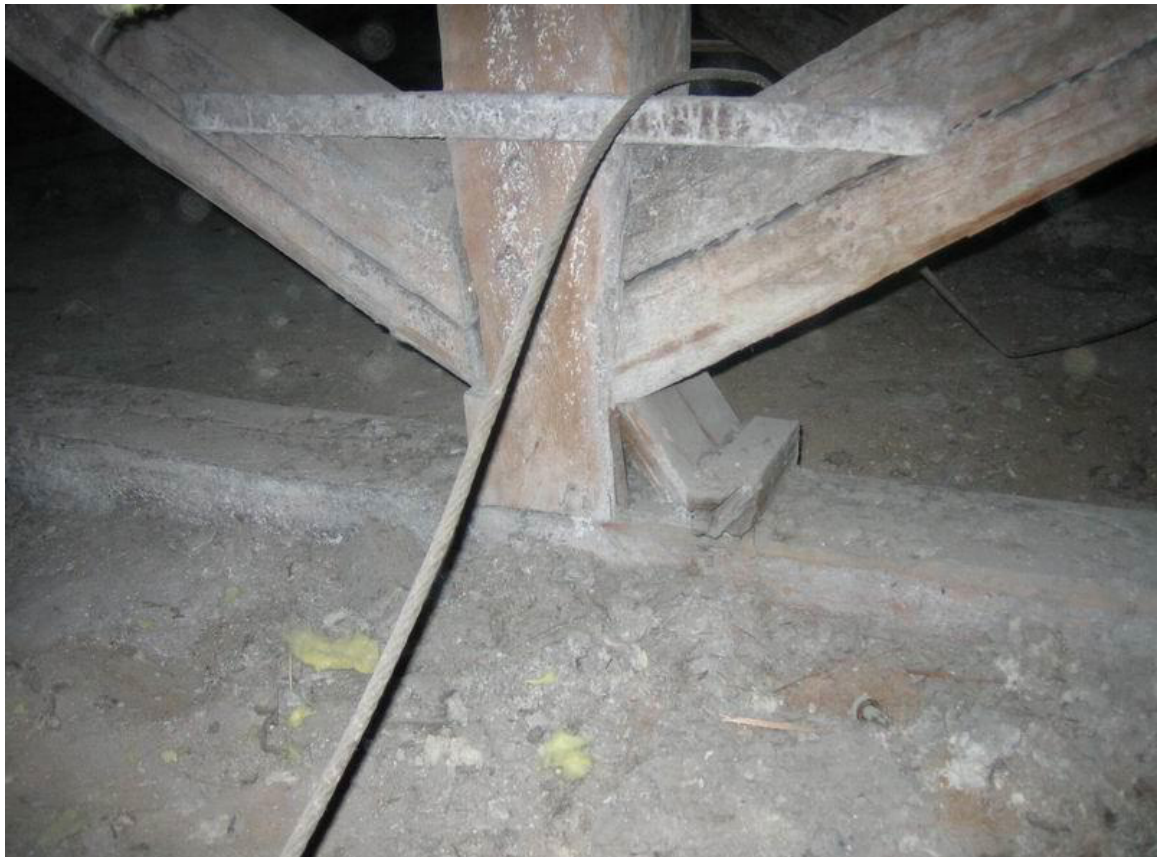

Fig. 6. Attic overlap on wooden beams; insulation - slag, construction debris

Administrative building in Vasilyevsky District, St. Petersburg was surveyed. [7] Time of construction is before 1917. In 1989 the building was overhauled with rearrangement of overlaps. The site is located within the boundaries of regulating built-up areas and economic activity of objects of cultural heritage.

The attic floor is flat on the metal beams, arranged with $800-900 \mathrm{~mm}$ increment in the axes 2-3 / A-I and 1100-1200 $\mathrm{mm}$ in axes 6-7 / A-I, with a filling of small-sized concrete ribbed slabs (Fig.7).

Floor beams in different spans of the building are I-section beams №22, №30; №24 [8] and the compound welded beams which consist of channel №24 and $63 \times 6$ corner; compound welded beams made of channel №22 and 63×6 corner.

The space between the beams is filled with expanded clay gravel and slag. In some places above the concrete ribbed slabs vapor barrier was designed made of bitumen-based materials and mineral wool.

The layers of the attic slab:

- Filling with expanded clay with density $\rho=900 \mathrm{~kg} / \mathrm{m} 3$; thickness $\delta=0.17 \mathrm{~m}$;

- Concrete ribbed slabs $-\rho=900 \mathrm{~kg} / \mathrm{m} 3 ; \delta=0.06 \mathrm{~m}$;

- Plaster $-\rho=1600 \mathrm{~kg} / \mathrm{m} 3 ; \delta=0.03 \mathrm{~m}$.
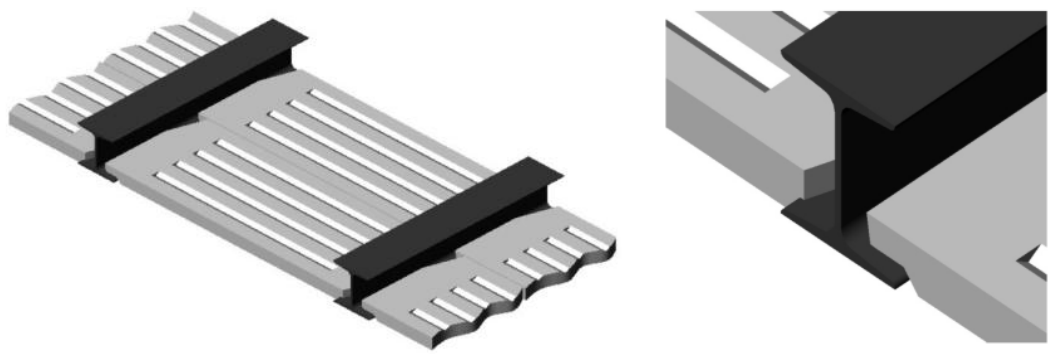

Fig. 7. Reinforced concrete ribbed slabs on steel load-bearing structures 
The attic slab above the staircase is presented as a lightweight vault which is $1 \mathrm{~m}$ height, made of hollow ceramic tubes shaped as corrugated cylinder (Fig. 8). The gaps were filled with the debris (slag, broken bricks, expanded clay gravel, etc.), with density $\rho=1200 \mathrm{~kg} /$ $\mathrm{m} 3$.
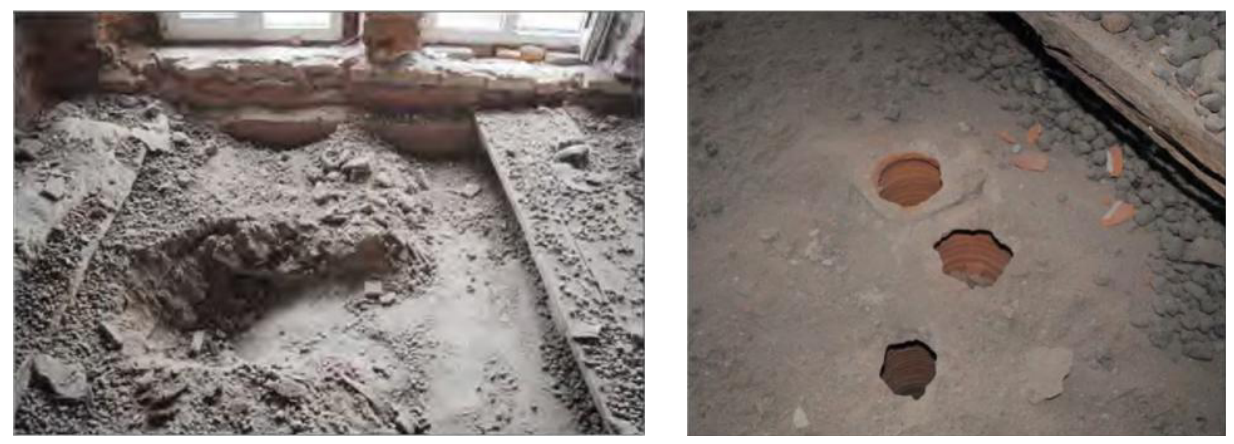

Fig. 8. Vault overlap over the staircase

As shown by field researches, wooden beams are often in good condition and can be preserved. In the opposite case, the reconstruction of overlapping is made with full or partial replacement of the load-bearing structure.

\section{Reconstruction of the floors of historical buildings with preservation of the ceiling}

We choose the worst case for the study, when the bearing capacity of the wooden ceiling is exhausted, but its replacement is not possible because of the need to preserve the historical ceiling (as part of the interior in the protected building - object of cultural heritage).

The design choice may be to preserve combustible ceiling and create reinforced concrete diaphragm above it which is $120 \mathrm{~mm}$ thick. Firstly, the old filling and insulating layers of strainer are removed, then wooden boards are laid on old beams (as permanent formwork) and monolith concrete slab-diaphragm is made. During monolithic works it is necessary to ensure an insertion of steel anchors (for the suspension of the old wooden beams of the ceiling) and overall stability of the entire structure (additional supports are made while mounting if necessary). By the means of anchors the load from combustible overlap is transmitted to the reinforced concrete slab. The design is shown in Fig. 9 [11].

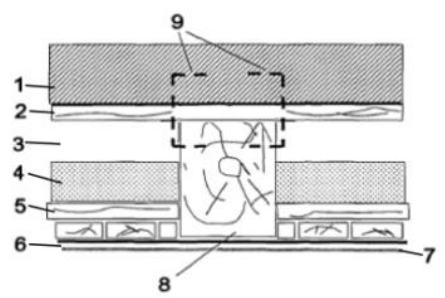

1 - concrete slab - $120 \mathrm{~mm}$;

2 - formwork of boards - $34 \mathrm{~mm}$;

3 - air gap - $120 \mathrm{~mm}$;

4 - filling (sand, crushed bricks) + insulating layer

(clay coating) - $80 \mathrm{~mm}$;

5 - double-layered boards - $80 \mathrm{~mm}$;

6 - supporting boards - $25 \mathrm{~mm}$;

7 - plaster on lath - $25 \mathrm{~mm}$;

8 - wooden floor beams $200 \times 280 \mathrm{~mm}$;

9 - steel anchors.

Fig. 9. The design of overlap reconstruction with the preservation of valuable ceiling 


\section{Thermal calculation of warming layer (for the climatic conditions of St. Petersburg)}

For calculation following conditions were determined: internal air temperature $+20{ }^{\circ} \mathrm{C}$, outside air temperature $-24{ }^{\circ} \mathrm{C}$, the number of degree-days in heating season is $4537{ }^{\circ} \mathrm{C} \cdot \mathrm{d}$, required thermal resistance of the attic slab is determined as $4.4685 \mathrm{~m} 2 \cdot{ }^{\circ} \mathrm{C} / \mathrm{W}$.

The values are taken as for roof structure. The calculation considers outdoor temperature, i.e. the " $n$ " factor was not considered.

The calculation is performed according to CP 50.13330.2012 "Thermal performance of the buildings". According to this newly integrated document, the outdoor air temperature during the heating period and the duration of the heating period is changed, so the number of degree-days of heating period changed too (CP 131.13330.2012 "Building climatology").

DDHS (degree-days in heating season $)=(20+1.3) \cdot 213=4537$;

$$
\begin{array}{ll}
\mathrm{R}_{\mathrm{req}}=0.0005 \cdot 4537+2.2=4.6585 & \text { - for roof structure; } \\
\mathrm{R}_{\mathrm{req}}=0.00045 \bullet 4537+1.9=3.94 & \text { - for attic overlap. }
\end{array}
$$

The temperature field of the original design is shown in Fig. 10. Thermal resistance of the attic overlap with the concrete diaphragm which is $120 \mathrm{~mm}$ thick and formwork thickness $34 \mathrm{~mm}-1.283 \mathrm{~m}^{2} \cdot{ }^{\circ} \mathrm{C} / \mathrm{W}$.

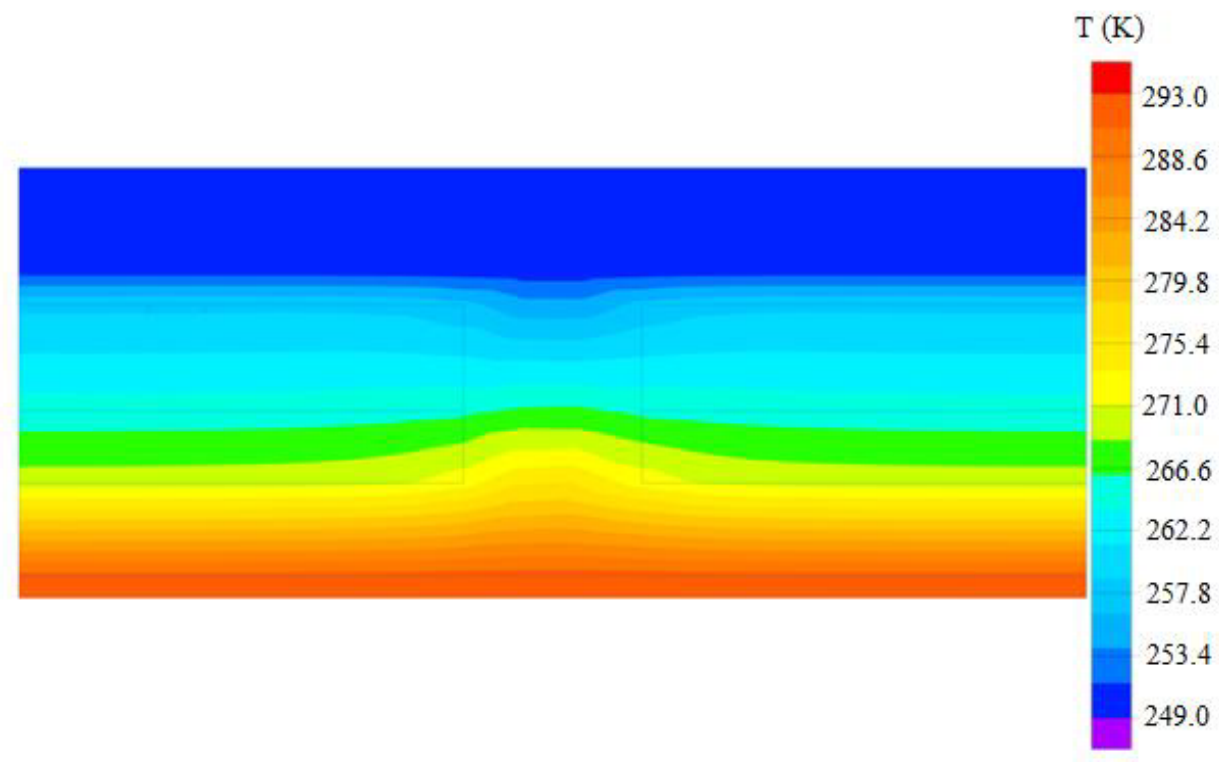

Fig. 10. Thermal field. Initial design.

As the insulation rock wool plates were selected, with density of $180 \mathrm{~kg} / \mathrm{m} 3$ and 160 $\mathrm{mm}$ thick. The temperature field is shown in Fig. 11. The thermal resistance of the attic slab with insulation $-4.617 \mathrm{~m} 2 \cdot{ }^{\circ} \mathrm{C} / \mathrm{W}$. 


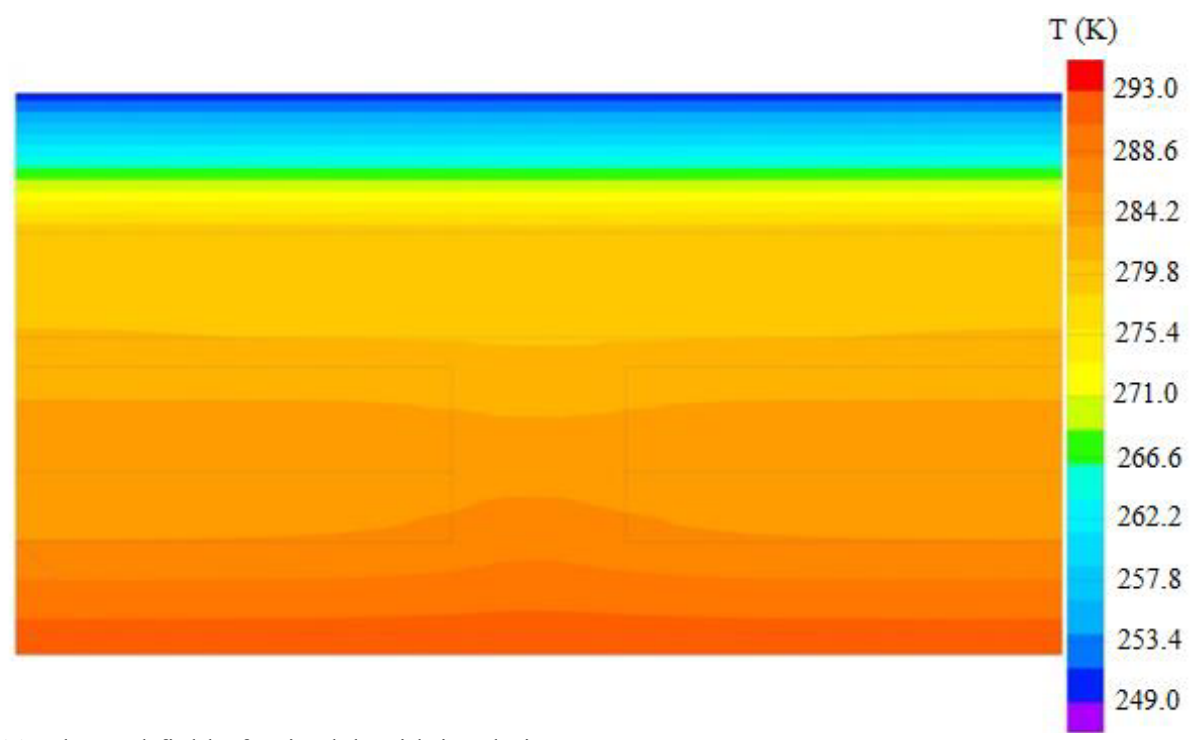

Fig. 11. Thermal field of attic slab with insulation.

\section{Conclusions}

The maximum preservation principle of historical structures of pre-industrial period buildings should be fundamental during the energy modernization of the old housing. Resolved design of reinforcing attic slab with its subsequent insulating allows the use of modern, efficient insulation materials without the risk of condensation in the layers of preserved wooden floor, which often occurs during the immediate installation of effective heat insulation on existing wooden slabs.

\section{References}

1. E. Arumägia, M. Mändelb, T. Kalamees, Energy Procedia. 78, 1027 - 1032 (2015)

2. C. D. Şahin, Z. D. Arsan, et al. Energy and Buildings, 96, 128-139 (2015)

3. L. L. Pisello, A. Petrozzi, V. L. Castaldo, F. Cotana, Applied Energy, 162, 1313-1322 (2016)

4. F. Ceroni, F. Ascione, R. F. De Masi, et al. Energy Procedia. 75, 1325-1334 (2015)

5. P. Leardini, M. Manfredini, M. Callau, Energy and Buildings. 95, 211-218 (2015)

6. K. Fabbri, B. Brunetti, Energy Procedia, 78, 1281-1286 (2015)

7. S.G. Golovina, S.V. Sementsov, Istoriya razvitiya konstruktsiy zdaniy zhiloy istoricheskoy zastroyki na primere Sakt-Peterburga, (SPbGASU, Saint-Petersburg, 2012)

8. G.T. Popov, L.Ya Burak, Tekhnicheskaya ekspertiza zhilykh zdaniy staroy zastroyki, (Stroyizdat, Leningrad, 1986)

9. V. Statsenko. Chasti zdaniy. Grazhdanskaya arkhitektura, (Gosudarstvennoe izdatel'stvo, Leningrad, 1930)

10. Information on: http://dl.unilib.neva.ru/dl/694.pdf

11. D. A. Slepukhin, PhD thesis. Moscow, 2001, 154 p. 